\title{
Perceived Intensity of Stress Stressors: A Study on Commercial Bank in Bangladesh
}

\author{
Md. Hasebur Rahman ${ }^{1}$, Md. Kamruzzaman², Md. Enamul Haque ${ }^{3}$, Md. Abdullah Al Mamun ${ }^{4}, \&$ \\ Md. Ibrahim Molla ${ }^{5}$
}

${ }^{1}$ Lecturer, Department of Business Administration, Pabna University of Science and Technology, Bangladesh

${ }^{2}$ Assistant Professor and Proctor, Pabna University of Science and Technology, Bangladesh

${ }^{3}$ Lecturer, Department of Economics, Pabna University of Science and Technology, Bangladesh

${ }^{4}$ Lecturer, Department of Business Administration, Pabna University of Science and Technology, Bangladesh

${ }^{5}$ Lecturer, Department of Business Administration, Pabna University of Science and Technology, Bangladesh

\begin{abstract}
Job stress becomes an important agenda for managers and management scholars now a days and it will remain in future. Organizational Stress is receiving increasing attention in the academic literature and has become a salient issue for the organizations. Job life is one of the important parts of our daily lives which cause a great deal of stress. This study is an initiative to explore how does stress stressors influences on work life of employees in contemporary commercial banks in Bangladesh. Study reveals that employees perceived that long working hour and workload have perceived as top most stressors of both public and private commercial banks in Bangladesh. It is statistically significant that there is no perceived difference in stress stressors of public and private commercial bank in Bangladesh.
\end{abstract}

Key words: Job Stress, Public Commercial Bank, Private Commercial Bank, Employees, Bangladesh

JEL Classification Code: E31

\section{INTRODUCTION}

Ctress is something ordinary, unavoidable fact in anyone life, caused by many factors either at work, or with the family at home, or at the external environment (Jarinto, 2011). According to Wilton (2011) it affects both the human resources and the management at the same time. Job stress is a new old concept, introduced first by Selye at the beginning of the twenty century and recently became one of the most important contemporary issues in applied research, the factors that lead to stress, its' consequences and the necessary strategies to deal with distress outcomes. It is existed in the life of every individual, within the family relations, at work and in any career, in any organization, all over the world (Akif Lutfi, AL-Balqa, 2013). There is considerable evidence that most managers and employees report feeling work related stress (Cavanaugh, Wendy, Boswell, Mark, Roehling, Boudreau, 2000) and resent environment is making things worse. Stress is still one of the most important and serious problems facing the field of organizational behavior.

Banking job is now one of the dynamic and challenging jobs in Bangladesh. Employees of commercial bank serve banking customer at competitive pressure. Due to increasing workload, job insecurity, deadline, long working hour and pressure from management, employees of commercial bank in Bangladesh perceived high job stress. As a result, there is much concern that stress level are on the rise, which leads to negative organizational outcomes. Employees become distress mentally and physiologically due to high work related stress.

\section{LITERATURE REVIEW}

Stress is still one of the most important and serious problems facing the field of organizational behavior. Stress is usually thought of in negative term applied to the pressures people feel in life. The presence of stress at work is almost inevitable in many jobs. Although there are numerous definitions and much debate about the meaning of job stress (A. Beehr, 1986). The stress itself will be affected by number of stressors. Nevertheless, Beehr and Newman (1978) had defined stress as a situation which will force a person to deviate from normal functioning due to the change (i.e. Disrupt or enhance) in his/her psychological and/or physiological condition, such that the person is forced to deviate from normal functioning. Stress can be comprehensively defined as an adaptive response to an external situation that results in physical, psychological, and/ or behavioral deviations for organizational participants (Luthans, 2011).

Employees are exposed to different situations that can lead to stress. These factors of making individuals stressed are called stressors. Either they have bad or good impact; it depends on how the person perceives this stressor and how much it affects his life (Sen, 2008). Ivancevich et al. (2008) and Kreitner and Kincki (2010) presented four levels of stressors in the individual life:

- Individual level which consists of role conflict, role ambiguity and role overload, boredom and routine under load jobs.

- Group levels: lack of cohesiveness inside the same group and groups' conflict. 
- Organizational level: culture, organizational structure, technology, organizational change and the style of leadership.

- Non work (Extra organizational) stressors: family, age, quality of life and economic factors.

According to Wilton (2011) the job stress is synchronized with bad quality of life at work, low degree of autonomy and control over individual jobs, their decisions and the work processes. Salami et al. (2010) considered instability in the organizations' policies, rules and procedures due to continuous change, strategic alliances or acquisitions can be major stressors in any organization. According to Rue and Byars (2007), working conditions with unpleasant organizational climate, the physical environment: light, temperature, noise and the rigidity of rules and regulations are job stressors. Role conflict according to Mansoor (2011) that is caused by multiplicity of roles and the contradictory requirements and duties between these roles, Rao and Borkar (2012) believed that employees uncertainty of their abilities; if they had sufficient qualifications to fulfill job requirements, lack of knowledge and skills opposite to task demands will end in internal conflict and job stress. Physical environment and how much it is convenience and fit employees' expectations. Buchanan and Huczynski (2004) and Jaramillo et al. (2011) provide insights on the interpersonal relations inside the organization, coworkers and conflict inside work groups that can range from hidden behaviors and disagreement up to the physical harm. Applied to the work place, a large study by researchers at Cornell University of 1800 managers identified examples of "bad" stress as office politics, red tape, and a stalled career and "good "stress as challenges that come with increased job responsibility, time pressure, and high quality assignments (HR Focus, 1999). A recent Meta -analysis found that hindrance stressors (organizational politics, red tape, role ambiguity, and in general those demands unnecessarily thwarting personal growth and goal attainment) had a negative effect on organizational performance. On the other hand, so called challenge stressors (high workload, time pressure, high responsibility and in general those demands that viewed as obstacles to be overcome in order to learn and achieve) were found to have effect on motivation and performance (Yerkes, Dodson, 1908).

\section{ObJectives of THE Study}

The study aims to obtain the following objectives:

- To identify the most important factors that lead to stress for employees of commercial bank in Bangladesh.

- To investigate perceive difference of stress stressors of public and private commercial bank in Bangladesh.

\section{Methodology}

This study mainly based on primary data originating from a survey. On the basis of preliminary questionnaire survey researchers attempt to identify factors responsible for job stress of employees of commercial bank in Bangladesh. Long working hour, workload family sympathy, management pressure, mental depression, deadline, poor working conditions, physiological sickness, role ambiguity and job insecurity are identified as independent variables causing stress in work place in commercial bank in Bangladesh. Survey was investigated through 5 point Brayfield-Rothe Scale (1951) based questions. Questionnaires were served to 70 employees working in commercial bank in sample organization. The scale consists of 10 statements concerning stress stressors of commercial bank. For each statement has five options/ points such as strongly agree/ 5, agree/ 4, undecided/ 3, disagree/ 2, and strongly disagree/ 1. SPSS Statistics software package was used for statistical analysis. Reliability of data was measured by using the Chronbach's Alpha (Cornbach, 1951). Chronbach Alpha was 0.567 and 0.685 for public and private commercial banks respectively. Alpha in both cases were higher than that is suggested by Nunnally (1978) and therefore data collected can be considered reliable. Descriptive statistical technique such as mean and standard deviation were used to measure the mean scores and their variability. One way ANOVA test was used to compare score of each statement.

\section{Results and Discussion}

Intensity of stressors perceived by employees

Table 1 represents the relative intensity of stressors perceived by employees.

Table 1 The Relative intensity of stressors

\begin{tabular}{|c|c|c|c|c|c|c|}
\hline \multirow{2}{*}{$\begin{array}{l}\text { Stress } \\
\text { Stressors }\end{array}$} & \multicolumn{3}{|c|}{$\begin{array}{c}\text { Public } \\
\text { Commercial Bank }\end{array}$} & \multicolumn{3}{|c|}{$\begin{array}{c}\text { Private } \\
\text { Commercial Bank }\end{array}$} \\
\hline & Ranking & $\bar{X}$ & $\sigma$ & Ranking & $\bar{X}$ & $\sigma$ \\
\hline $\begin{array}{l}\text { Long working } \\
\text { hour }\end{array}$ & 1 & 4.40 & 1.063 & 1 & 4.40 & 1.063 \\
\hline Workload & 2 & 4.20 & .901 & 2 & 4.20 & .901 \\
\hline $\begin{array}{l}\text { Family } \\
\text { Sympathy }\end{array}$ & 3 & 4.00 & .907 & 4 & 3.63 & 1.140 \\
\hline $\begin{array}{l}\text { Management } \\
\text { Pressure }\end{array}$ & 4 & 3.63 & 1.087 & 3 & 3.63 & 1.003 \\
\hline $\begin{array}{l}\text { Mental } \\
\text { Depression }\end{array}$ & 5 & 3.60 & 1.168 & 7 & 3.03 & 1.098 \\
\hline Deadline & 6 & 3.49 & 1.222 & 5 & 3.57 & .917 \\
\hline $\begin{array}{l}\text { Poor Working } \\
\text { Conditions }\end{array}$ & 7 & 3.17 & 1.294 & 9 & 2.11 & 1.323 \\
\hline $\begin{array}{l}\text { Physiological } \\
\text { sickness }\end{array}$ & 8 & 2.71 & 1.426 & 10 & 2.11 & 1.132 \\
\hline Role Ambiguity & 9 & 2.54 & 1.221 & 8 & 2.17 & 1.150 \\
\hline Job Insecurity & 10 & 2.37 & 1.285 & 6 & 3.06 & 1.327 \\
\hline
\end{tabular}

Source: Field Survey, 2013.

From the table 1 it reveals that long working hour and workload perceived as top stressors of both public and private commercial bank in Bangladesh. Interestingly mean and standard deviation are same in both cases. It indicates inconvenient work schedule perceived by employees in commercial bank in Bangladesh Mean value of family 
sympathy 4.00 and 3.63 for public and private commercial bank in Bangladesh however high variability observed in private commercial bank in Bangladesh. It indicates they spend inadequate time for family in both cases. Mean value of management pressure is 3.63 in both type of organization. It indicates management pursue for above average performance for high profitability of business. Mean value of mental depression are 3.60 and 3.03 for public and private commercial bank. It indicates high level of depression due to high job stress (mean value above 2.5). Mean value of deadline 3.49 and 3.57 perceived as a high stress, indicate urgency to meet deposit target, number of account to be open, amount of loan to be sanctioned with reference to individual employees for fulfilling promotional requirements. Poor working condition perceived high stress stressors for public low for private mean vale 3.17 and 2.11 respectively. In case of physiological sickness, role Ambiguity public commercial bank is slightly higher than private commercial bank. Mean value of job insecurity is higher for private than public commercial bank 2.37 and 3.06 mean value respectively. It indicates that public commercial bank has high job autonomy than that of private commercial bank in Bangladesh. Therefore difference in stress intensity observed in commercial bank in Bangladesh.

\section{Perceive differences of stress stressors}

This section investigates perceive difference of stress stressors of public and private commercial bank in Bangladesh.

One way ANOVA test has been used to test difference in perception of employees on stress stressors of commercial bank in Bangladesh. Employees of public and private commercial significantly of poor working condition issue ( $\mathrm{F}$ value $11.414, \mathrm{p}$ at $5 \%$ level of sig. is .001). Other stressors like workload, long working hour, deadline, job insecurity, physiological sickness, management pressure, family sympathy, role ambiguity and mental depression alike to be same, therefor there is no significant differences observed in perception of employees of existing stress stressors of public and private commercial bank in Bangladesh (average value of $F$ is 2.778 and $p$ is 0.338 at 0.05 level of significance).

\section{CONCLUSION}

The study identifies employees of commercial bank as one the occupational group that functions under conditions of high stress. The variables such as long working hour, workload, family sympathy, management pressure, mental depression, deadline, poor working conditions, physiological sickness, role ambiguity and job insecurity perceived stress stressors of commercial bank in Bangladesh. There for variability observed in public and private commercial bank in Bangladesh. Employees wellbeing psychologically and mentally depress if stress prolong over the period of time. Effective job design, healthy working environment, justifiable remuneration should be offered to employees being motivated in competitive jobs like employees of commercial bank in Bangladesh.

\begin{tabular}{|c|c|c|c|c|c|c|}
\hline \multicolumn{7}{|c|}{ Table:2 One way ANOVA } \\
\hline & & $\begin{array}{l}\text { Sum of } \\
\text { Squares }\end{array}$ & $\mathrm{df}$ & $\begin{array}{l}\text { Mean } \\
\text { Square }\end{array}$ & $\mathrm{F}$ & Sig. \\
\hline Workload & $\begin{array}{l}\text { Between Groups } \\
\text { Within Groups } \\
\text { Total }\end{array}$ & $\begin{array}{c}.057 \\
51.886 \\
51.943\end{array}$ & $\begin{array}{l}1 \\
68 \\
69\end{array}$ & $\begin{array}{l}.057 \\
.763\end{array}$ & .075 & .785 \\
\hline $\begin{array}{l}\text { Long } \\
\text { working } \\
\text { hour }\end{array}$ & $\begin{array}{l}\text { Between Groups } \\
\text { Within Groups } \\
\text { Total }\end{array}$ & $\begin{array}{c}.700 \\
52.800 \\
53.500\end{array}$ & $\begin{array}{l}1 \\
68 \\
69\end{array}$ & $\begin{array}{l}.700 \\
.776\end{array}$ & .902 & .346 \\
\hline Deadline & $\begin{array}{l}\text { Between Groups } \\
\text { Within Groups } \\
\text { Total }\end{array}$ & $\begin{array}{c}.057 \\
68.743 \\
68.800\end{array}$ & $\begin{array}{l}1 \\
68 \\
69\end{array}$ & $\begin{array}{l}.057 \\
1.011\end{array}$ & .057 & .813 \\
\hline $\begin{array}{l}\text { Job } \\
\text { insecurity }\end{array}$ & $\begin{array}{l}\text { Between Groups } \\
\text { Within Groups } \\
\text { Total }\end{array}$ & \begin{tabular}{|c|}
8.229 \\
116.057 \\
124.286
\end{tabular} & $\begin{array}{l}1 \\
68 \\
69\end{array}$ & $\begin{array}{l}8.229 \\
1.707\end{array}$ & 4.821 & .032 \\
\hline $\begin{array}{l}\text { Physio } \\
\text { logical } \\
\text { sickness }\end{array}$ & $\begin{array}{l}\text { Between Groups } \\
\text { Within Groups } \\
\text { Total }\end{array}$ & \begin{tabular}{|c|}
6.300 \\
112.686 \\
118.986
\end{tabular} & $\begin{array}{l}1 \\
68 \\
69\end{array}$ & $\begin{array}{l}6.300 \\
1.657\end{array}$ & 3.802 & .055 \\
\hline $\begin{array}{l}\text { Poor } \\
\text { working } \\
\text { conditions }\end{array}$ & $\begin{array}{l}\text { Between Groups } \\
\text { Within Groups } \\
\text { Total }\end{array}$ & \begin{tabular}{|c|}
19.557 \\
116.514 \\
136.071 \\
\end{tabular} & $\begin{array}{l}1 \\
68 \\
69\end{array}$ & $\begin{array}{l}19.557 \\
1.713\end{array}$ & 11.414 & .001 \\
\hline $\begin{array}{l}\text { Manage } \\
\text { ment } \\
\text { pressure }\end{array}$ & $\begin{array}{l}\text { Between Groups } \\
\text { Within Groups } \\
\text { Total }\end{array}$ & $\begin{array}{c}.014 \\
80.571 \\
80.586\end{array}$ & $\begin{array}{l}1 \\
68 \\
69\end{array}$ & $\begin{array}{l}.014 \\
1.185\end{array}$ & .012 & .913 \\
\hline $\begin{array}{l}\text { Family } \\
\text { sympathy }\end{array}$ & $\begin{array}{l}\text { Between Groups } \\
\text { Within Groups } \\
\text { Total } \\
\end{array}$ & $\begin{array}{l}2.414 \\
72.171 \\
74.586\end{array}$ & $\begin{array}{l}1 \\
68 \\
69\end{array}$ & $\begin{array}{l}2.414 \\
1.061\end{array}$ & 2.275 & .136 \\
\hline $\begin{array}{l}\text { Role } \\
\text { ambiguity }\end{array}$ & $\begin{array}{l}\text { Between Groups } \\
\text { Within Groups } \\
\text { Total }\end{array}$ & $\begin{array}{l}2.414 \\
95.657 \\
98.071\end{array}$ & $\begin{array}{l}1 \\
68 \\
69\end{array}$ & $\begin{array}{l}2.414 \\
1.407\end{array}$ & 1.716 & .195 \\
\hline $\begin{array}{l}\text { Mental } \\
\text { depression }\end{array}$ & $\begin{array}{l}\text { Between Groups } \\
\text { Within Groups } \\
\text { Total }\end{array}$ & $\begin{array}{c}3.657 \\
91.714 \\
95.371\end{array}$ & $\begin{array}{l}1 \\
68 \\
69\end{array}$ & $\begin{array}{l}3.657 \\
1.349\end{array}$ & 2.712 & .104 \\
\hline Average: & & & & & 2.778 & 0.338 \\
\hline
\end{tabular}

\section{REFERENCE}

A. Beehr, "The Current Debate about the Meaning of Job Stress, 1986." Journal of Organizational Behavior Management, Fall/Winter, pp. 5-18.

A. Cavanaugh, Wendy R. Boswell, Mark V.Roehling, and John W. Boudreau, 2000. "An Empirical Examination of SelfReported Work Stress among U.S. Managers," Journal of Applied Psychology, Vol.85, pp. 65-74.

Akif Lutfi, AL-Balqa, 2013. The Relationship between Job Stress and Nurses Performance in the Jordanian Hospitals: A Case Study in King Abdullah the Founder Hospital, Asian Journal of Business Management, 5(2): 267275,

Beehr, T.A. and Newman, J.E. 1978, Job stress, employee health, and organizational effectiveness: a facet analysis, model and literature review, Personnel Psychology, 31(4), pp. 665-99. 
Buchanan, D. and A. Huczynski, 2004. Organizational Behavior: An Introductory Text. 5th Edn., Prentice Hall Financial Times, Harlow, pp: 157.

Cronbach L.J (1951) "Coefficient Alpha and Internal Structure of Test". Psychometrika. Vol. 16, pp.297-334.

Ivancevich, J.M., R. Konopaske and M.T. Matteson, 2008. Organizational Behavior and Management. 8th Ed., McGraw Hill Irwin, Boston, New York, pp.: 224-227.

Jaramillo, F., J.P. Mulki and J.S. Boles, 2011. Workplace stressors, job attitude and job behaviors: Is interpersonal conflict the missing link? J. Pers. Sell. Sales Manag., 31(3): 339-356.

Jarinto, K., 2011. Understanding Stress in Multinational Companies in Thailand. Int. Bus. Res., 4(4): 153-163

Kreitner, R. and A. Kinicki,. 2010. Organizational Behavior. 9th Ed., McGraw Hill Irwin, Boston, pp.: 556-558.

Luthans F., Organizational Behavior, 1998, Eighth Edition, Irwin -McGraw Hill, India, pp.279.

Mansoor, M., 2011. The impact of job stress on employee job satisfaction: A study on telecommunication sector of Pakistan. J. Bus. Stud. Quart., 2(3): 50-56.
R. M. Yerkes and J. D. Dodson, (1908): “The relation of strength of stimulus to rapidity of habit-formation," Journal of Comparative Neurology and Psychology, 18, pp.459-482.

Rao, S. and S. Borkar, 2012. Development of scale for measurement of stress and performance status of public and private sector bank employees. Indian Stream. Res. J., 2(7): 1-7.

Reported in "HR Focus", April 1999, p.4.

Rue, L.W. and L.L. Byars, 2007. Management: Skills and Application. 12th Ed., McGraw Hill Irwin, Boston, pp.: 348-350.

Salami, A.O., R.M. Ojokuku and O.A. Ilesanmi, 2010. Impact of job stress on managers' performance. Eur. J. Sci. Res., 45(2): 249-260.

Sen, S., Executives and the Stress Factor. The Icfai University Press, pp.: 39-44. 2008

Wilton, N., 2011. An Introduction to Human Resource Management. SAGE, Los Angeles, pp.: 113-419.

Wilton, N., 2011. An Introduction to Human Resource Management. SAGE, Los Angeles, pp.: 113-419.

$$
--0--
$$

